\title{
Article \\ Applicability of Collaborative Work in the COVID-19 Era: Use of Breakout Groups in Teaching L2 Translation
}

\author{
Iman Oraif ${ }^{1, *}$ and Tariq Elyas ${ }^{2}(\mathbb{D}$ \\ 1 Department of English Language and Literature, College of Languages and Translation, \\ Imam Mohammad Ibn Saud Islamic University (IMSIU), Riyadh 3204, Saudi Arabia \\ 2 Department of Foreign Languages and Literature, Faculty of Arts and Humanities, \\ King Abdulaziz University, Jeddah 21589, Saudi Arabia; telyas@kau.edu.sa \\ * Correspondence: IMOraif@imamu.edu.sa
}

check for updates

Citation: Oraif, I.; Elyas, T. Applicability of Collaborative Work in the COVID-19 Era: Use of Breakout Groups in Teaching L2 Translation. Electronics 2021, 10, 2846. https:// doi.org/10.3390/electronics10222846

Academic Editors:

Carlos Alario-Hoyos,

Mar Pérez-Sanagustín,

Miguel Morales, Oscar Jerez

and Boni García

Received: 26 October 2021

Accepted: 12 November 2021

Published: 19 November 2021

Publisher's Note: MDPI stays neutral with regard to jurisdictional claims in published maps and institutional affiliations.

Copyright: (c) 2021 by the authors. Licensee MDPI, Basel, Switzerland. This article is an open access article distributed under the terms and conditions of the Creative Commons Attribution (CC BY) license (https:/ / creativecommons.org/licenses/by/ $4.0 /)$.

\begin{abstract}
Social distancing became a must during the pandemic, which not only had implications for people's social lives, but also for their learning. Collaborative work was almost impossible, especially in the classroom, despite a great need for this approach. For example, in their translation classes, the learners needed to collaborate with their peers, assisting each other in translating texts. Thus, the use of breakout groups is proposed in this study, although there is no guarantee that learners will accept this online approach. Consequently, the current research looks at learners' acceptance of breakout groups on Blackboard in a translation class. To examine their acceptance, an existing scale was used, developed by Davis (1989) to measure two factors of technology acceptance: perceived usefulness and ease of use. A sample of 54 students on a Translation course at Al-Imam Mohammed Ibn Saud Islamic University in Riyadh, Saudi Arabia, participated in this study. The results show that the learners found breakout groups on Blackboard to be useful and easy to use.
\end{abstract}

Keywords: TAM; collaboration; breakout groups; COVID-19; translation; L2 learners; KSA

\section{Introduction}

Collaboration between learners may be noted throughout the literature as having a positive impact on learning. This is especially the case on courses that involve a high level of thinking and problem-solving skills [1] such as translation courses. In these instances, learners may prefer to collaborate traditionally by meeting face to face, but due to the pandemic, this was not possible. Instead, all learning was transferred online, with classes continuing in various online environments, known as virtual learning environments (VLEs), wherein learners could only collaborate via the virtual world. The most commonly used VLE in Saudi universities is Blackboard. This is a learning management system (LMS) with tools for developing a collaborative environment, such as breakout groups. Breakout groups enable learners to be allocated to different groups, whereupon they continue to work alone, while collaborating virtually with fellow group members. They cannot see the activities of other groups, but the teacher can enter each virtual room and check the learners' performances. On this basis, the present study explored the extent to which learners in a translation class find breakout groups on Blackboard useful and easy to use for working collaboratively in an online environment. An attempt will, therefore, be made to answer the following questions:

1. To what extent do learners in a translation class find breakout groups on Blackboard useful for working collaboratively?

2. To what extent do learners in a translation class find breakout groups on Blackboard easy to use for working collaboratively? 


\section{Literature Review}

\subsection{Online Learning in KSA throughout the Pandemic}

COVID-19 lockdowns caused school closures and the cancelling of commercial passenger flights [2], with tourism industries receiving a harsh hit, contributing to the crippling of the world economy. According to the World Health Organization [3], more than 37 million COVID-19 cases and 1 million deaths were reported globally from December 2019 to October 2020. Meanwhile, according to [4], a range of needs have demanded an imperative reform to education in Saudi Arabia and worldwide. The shift towards a new medium of teaching, without the physical presence of the teacher or student, has proven to be a major challenge to this change in educational settings. The physical medium that once gave presence, used by traditional methods to enact authority and control, is becoming obsolete [5]. According to few researchers [6], on the concept of online teaching in Saudi Arabia five years before the pandemic, they claim that the classroom environment has shifted to something different, something distant, taking away some control from the teachers and putting it entirely in the hands of the students. It also revealed how Saudi education had been slowly advancing conceptually. This manifested as incompatibility with the medium. It has been proven that teachers were struggling to cope with the changes to online teaching [6] many years before the impact of the COVID-19 pandemic. This mere transition of Saudi classrooms and the teacher's role remained supplemented with suitable changes that reflected present day societal advancements. The existence of COVID-19 forced a change to unfamiliar grounds [4]. However, it is not COVID-19 that made these new grounds unfamiliar, but the role itself had been stuck in a loop for generations, neglecting the potential for appropriate changes [7].

The teacher's role in online teaching both 'during COVID-19' and 'before the pandemic' is not merely to present the material, but rather to introduce students to creative methods [8], where the physical interaction is missing. Hence, the role would need to change from being authoritative to a cooperative, engaging, playful, and fun learning environment. In a cooperative classroom, teachers are part of an interactive environment that focuses on aural and visual stimulation [8]. Students become creators, shaping their own experiences independently and actively contributing to the shape of the classroom's environment through visual and aural manipulation, while the teacher would act as a creative guide who enhances their experiences through feedback [8].

COVID-19 has in fact created a new opportunity for teachers and Saudi education; in particular, they are presented with the opportunity look at education through an array of creative lenses. For instance, ref. [9] claims that 'without the outbreak of the pandemic, our schools and universities would have not practiced distance learning in such a fluent way'. The Saudi government has made sure that all its sectors (public and private) need to work together to prevent the spread of COVID-19. According to [10], the Ministry of Education (MoE) was in a dilemma. However, this type of 'online' education has its own culture, ideologies, and mechanisms that might be absent among some people [11], which may prove to a challenge for parents who are facilitating the learning of their stay-home children. A few researchers claim that online education services began years ago [4], but the systems were upgraded recently to deal with the COVID-19 pandemic [12]. Therefore, the Ministry of Education (MoE) has introduced several learning strategies to facilitate the distanced learning process for the students. They applied mechanisms and solutions of distance learning - establishing Ien TV channels, Ien on YouTube, the Ien virtual gate, and other electronic platforms, to accomplish eight million teaching hours, three million items of digital content, and three and half million virtual classrooms [13].

Many Saudi researchers have praised the work of MoE [13,14] for their upscaling of educational strategies during the pandemic. With the beginning of the current academic year, the Ministry of Education was ready to launch the new Madrasati platform and 23 TV channels, with a specific channel for each level, complementing what was set to be available and beneficial for each student, such as Future Gate, Saudi Virtual School, and the Virtual Kindergarten. The MoE has applied many educational policies to effectively 
enable students to make the most of these electronic and educational possibilities, assigning morning hours to the intermediate and secondary school students, and the afternoon hours to the elementary school students, in order for parents to follow up with their kids and help them through the process of distanced learning in the evening [14]. In the same vein, ref. [13] points out the important fact that the MoE is working closely with other ministries to ensure that each student has the necessary tools and resources to complete the school year via distanced learning. The aim is to broadcast during school time and accommodate students who lack internet access or who have no computers to access the platform [14]. In fact, the MoE has been doing the best job in dealing with education during the COVID-19 pandemic. Commenting on the ministry's pledge that students who could not afford computers would not be left behind, Alfaries stated that 'there are a number of initiatives and collaborations between the ministry and other organizations such as Takaful to help students who cannot afford the basic equipment to access the platform' [14]. The MoE was successful in providing 6 outstanding educational platforms-from which 3 million students benefitted - with TV channels achieving 61 million views, the Ien national educational gate having 45 thousand courses and two thousand school digital books, and the Ien channel on YouTube having 750,000 subscribers, with 5400 recorded lessons and 4000 live hours [15]. In fact, Barakat [16] stated that 'distance learning provided many educational courses as well as recorded lessons which students can accomplish at any time to increase their educational capabilities; and it is not restricted by the time of the class' [16]. Moreover, Barakat stated that 'distance learning does not support the idea of direct communication between the teacher and the student which may result in making the student lazy in his/her learning process because he/she is not under the domination of the teacher and the school administration' [16].

Regarding the same point, 'we may need to explore methods incorporate with online teaching to enhance students' engagement' [17]. The authors of this paper believe that there is still a huge gap between the students and the prospects of remote learning processes. It is also observed that some parents no longer follow the education of their kids these days because they underestimate the importance of remote learning.

During the period of the pandemic, universities and educational institutions proved their effectiveness in the educational process, especially in university education. A study carried out at King Khalid University aimed to assess academic staff satisfaction with suspending traditional teaching and shifting to online education, revealing that $55.9 \%$ out of the participants agreed or strongly agreed that the sudden shift to web-based education was done smoothly, and $57.6 \%$ agreed or strongly agreed that giving lectures remotely was more flexible than delivering face-to-face lectures [18]. Moreover, ref. [15] points out that the MoE is working, in cooperation with expertise international organizations, to conduct an extensive validating assessing study for distanced learning in universities and schools during the period of the pandemic and afterwards. In addition, ref. [4] conducted a study to explore learners' levels of engagement in online courses using a designated school platform within the context of Saudi Arabia. A reliable measure was implemented in their study, based on the Student Course Engagement Questionnaire (SCEQ), with a sample of 379 female English as a foreign language (EFL) learners, studying a general English language course. The results revealed a high level of engagement among EFL Saudi learners during the COVID-19 pandemic. Ref. [19], in their recent study, explored the challenges and support methods for $\mathrm{d} / \mathrm{Dhh}$ students during their distanced education in Saudi Arabia. A qualitative research study, using semi-structured interviews, was conducted with 37 parents of $\mathrm{d} / \mathrm{Dhh}$ students to answer research questions. Three themes emerged from the parents' responses, as follows: (1) the challenges faced by d/Dhh students in distanced education; (2) the specific needs of $\mathrm{d} / \mathrm{Dhh}$ students in distanced education; and (3) the supports provided to $\mathrm{d} /$ Dhh students in distanced education. They concluded that $\mathrm{d} /$ Dhh students require various forms of ongoing support from both their families and schools to ensure that they succeed and benefit from their experiences. In her study, ref. [20] investigated the experiences of English major students at the College of 
Language and Translation (COLT) in King Saud University, Saudi Arabia, with Emergency Remote Learning and Teaching (ERLT) during the COVID-19 crisis. A total of 150 students participated in the study. An online survey was carried out in the form of questionnaires to elicit their responses. The results showed that laptop computers were the dominant devices students used and preferred. They also revealed that the Zoom platform came first in students' preferences, followed by Blackboard. Additionally, the findings showed that, although participants used smartphones in their ERL, they did not recommend it, and it came last compared with laptops, tablets, and desktop computers in their order of preference.

\subsection{Breakout Groups and Language Learning}

The COVID-19 pandemic is forcing many institutions to consider remote, virtual instruction for the safety of employees and students [21]. Many online language teaching users found the plethora of learning technologies available to be overwhelming [22] Helping English language teachers select appropriate technologies is imperative now, more than ever. Many educators are divided about the benefits of online teaching and learning, especially in the current COVID-19 pandemic when such instruction is necessary and often accompanied by insufficient preparation [23].

Many instructors struggling to get their content online, for the first time ever tasks are carried out under great pressure, and crucial success factors for online teaching, which are being overlooked. Teaching online involves much more than creating a library of learning materials, streaming a lecture, or overloading learners with assignments [24]. Active learning is a broad term that includes a variety of different methods, which teachers can apply in the classroom [25]. A general breakdown of active learning will reveal three interrelated subsets, as follows: (a) collaborative learning; (b) cooperative learning; (c) problem-based learning (PBL) [25]. All of which are methods of instruction that aim to engage students in the learning process [26].

Meanwhile, breakout groups are employed across a wide range of settings, with most published reports describing their use in conferences [27], workshops [28]. However, it was claimed that breakout groups have been widely used on undergraduate programs [26]. Breakout sessions have therefore been a staple of face-to-face class sessions, and more recently have been employed in both asynchronous and synchronous online courses [28-31]. While the use of breakout rooms is widely studied, the intersection between breakout rooms and e-learning is left almost unexplored [32].

At this point in time, very little has been published regarding the use of breakout groups in a range of educational settings during the COVID-19 pandemic response to the use of breakout groups [26]. Because of the scarcity of research on breakout rooms (virtual or face-to-face), as described by [26], it is almost difficult to know how often students are provided with little or no structure to guide collaboration in real breakout room environments at this point. Therefore, this study seeks to fill the gap in the research on the use of breakout groups in Saudi Arabia during the COVID-19 pandemic.

In their study, ref. [33] used an exploratory case study design to gain insight into instructors' experiences with web-based synchronous communication using two-way audio and direct messaging. They conducted semi-structured interviews with eight instructors. They concluded that the use of text-based messaging and two-way audio raised issues in relation to the need to divide one's attention and in promoting student-student interaction during the breakout groups. Breakout groups have become very well known in Zoom software, used by many educators around the world. According to a couple of researchers [34], 'educators have utilized a range of online synchronous meeting tools (SMTs) to facilitate student learning'. One of the popular, immersive, and easy-to-use SMTs these days is Zoom, as it includes several features, such as annotation tools, polls, breakout rooms, and video and screen sharing. It has proved that using Zoom in an educational setting can facilitate communicative language learning through the use of authentic language instruction in interactive synchronous classes. However, other researchers have called 
upon future goals for blended learning, post the COVID-19 pandemic. Conversely, ref. [35] advocate for a more blended synchronous learning, claiming it has the potential to increase students' co-presence and improve upon the flexibility and accessibility of course offerings, if it is designed well.

In breakout research, a study has established an 'interactive, no-prep' approach, using breakout rooms within a videoconferencing system and requiring prior learner preparation. The authors found that, during the breakout groups, the learners produced perfectly effective study designs to answer the research question(s). Their results revealed that, as learners, they were well engaged in facilitated open discussion, and their learning outcomes were even [36].

\section{Methodology}

To gather data to address the research questions in this study, a survey was conducted with an existing case. The data were collected during March 2021 from a translation class in the English Department at Al-Imam Mohammed bin Saud University in Riyadh, KSA. The translation course was at the second level and focused on technical translation, before which, the learners were obliged to complete a prerequisite course in 'Cultural Translation'. The second language (L2) English learners involved used breakout groups for the final two classes of term, in order to collaborate in translating a text specified by their instructor. Two different Departmental sections were sampled. Ultimately, 54 students agreed to participate, out of the total population of 463 students who were studying translation at the time. The participants comprised a homogeneous sample of female students at university level six, studying Translation in the English Department, aged between 20 and 22 years. These study participants represented $11 \%$ of the whole population, which is considered to be a representative sample. The participants were exclusively female, due to the restrictions that are inherent to KSA.

Comprehensive sampling was applied in this current study, whereby all students in the translation class were included. A consent form was also signed by all the participants before completing the questionnaire. At the end of the second class, the instructor herself sent a link to the participants via the Blackboard chat window, so that they could access and complete the questionnaire.

The participants were all taught by the same teacher and covered the same material during both classes. The students met their teacher twice a week for three hours. On the Translation course, different types of texts were studied and translated throughout the 12 weeks of teaching, for example, political, medical, financial, and law texts. Breakout groups were created for the classes. Here, the learners practiced translating texts such as tenancy agreements. In the first class, these law texts were translated from Arabic (the source text) to English (the target text). Meanwhile, in the second class, the students translated from English (the source text) to Arabic (the target text).

The researcher observed the classroom procedure with the instructor's permission and without interrupting or distracting her class. During the breakout groups, the instructor randomly allocated the students to different groups, with each group consisting of 5-7 students. These groups worked on translating the text for half an hour at the end of the lesson, after which they sent their work to the instructor. The groups then reviewed their translations with the instructor at the beginning of the next translation lesson, as a whole class discussion. Examples of collaboration between the students were recorded by the researcher without interrupting or disturbing the participants, and only after gaining permission from the instructor (Figures 1 and 2). 


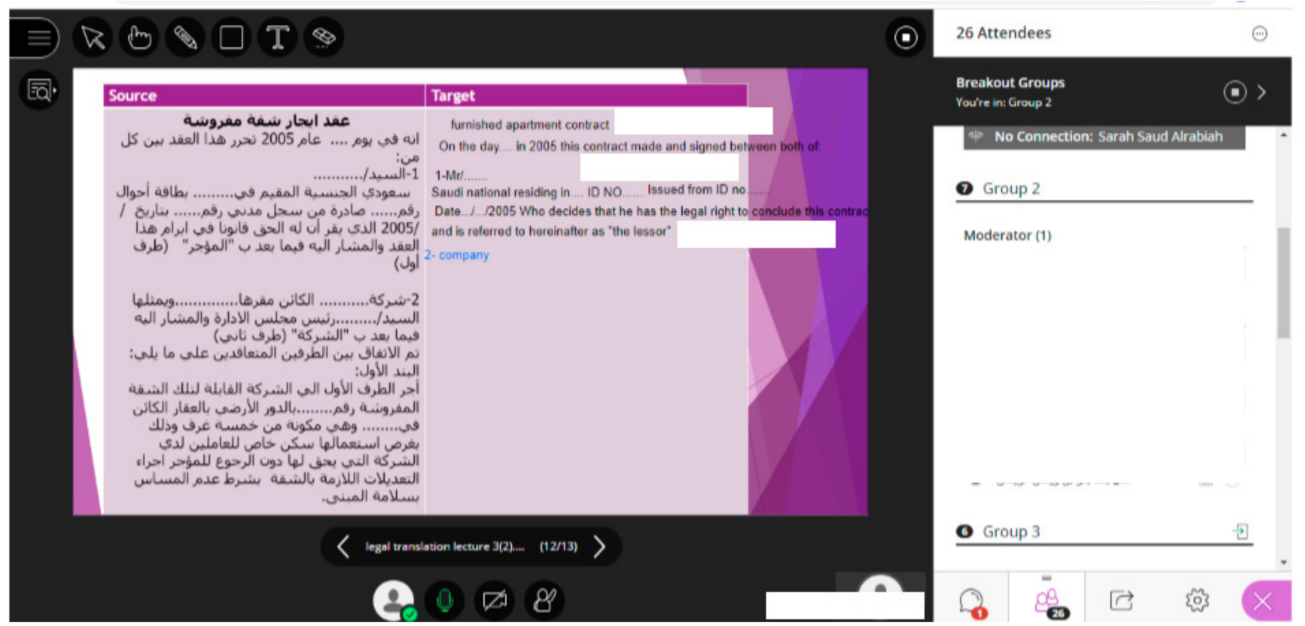

Figure 1. Sample of students' interaction in one of the groups.

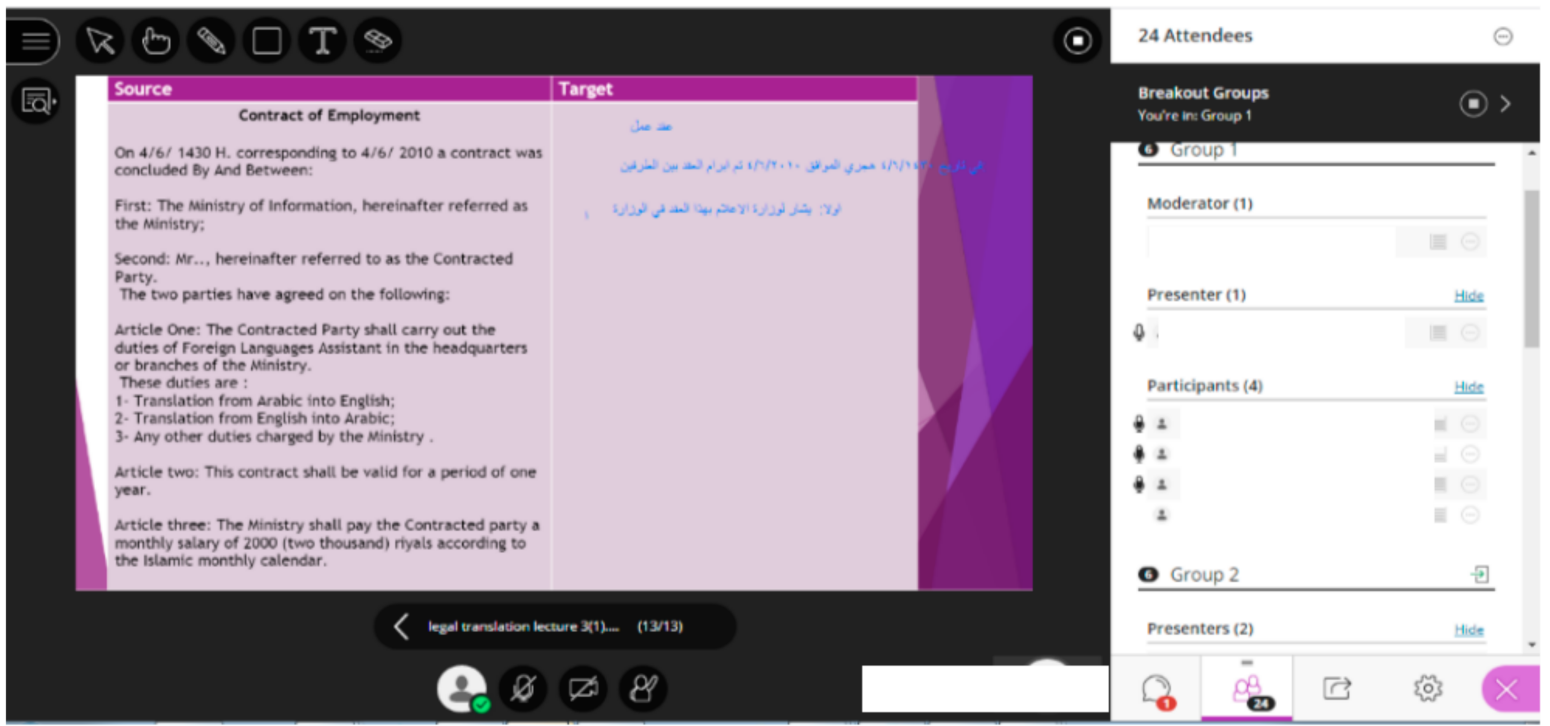

Figure 2. Sample of students' interaction in one of the groups.

The Survey

The survey used in this current study was adapted from [37], who stated that there are many variables that can affect people's acceptance of technology. However, previous research suggests that the most common variables include the extent to which people find an application helpful for performing their job more effectively (perceived usefulness) [37] and the extent to which people find an application easy to use (perceived ease of use) [37]. In this regard, Davis defined these two variables as follows: '[Perceived usefulness is] the degree to which a person believes that using a particular system would enhance his or her job performance'; while perceived ease of use refers to 'the degree to which a person believes that using a particular system would be free of effort' [37]. The original scale developed by Davis consisted of a 7-point Likert scale based on the results from his pilot study conducted with 120 participants, and it was adopted in the current research as it was found to be easily understood by the participants (Extremely Unlikely, Quite Unlikely, Slightly Unlikely, Neither Likely nor Unlikely, Slightly Likely, Quite Likely, and Extremely Likely) [37].

The theoretical foundation of perceived usefulness was driven by [38-42]. Conversely, the importance of ease of use is supported by Bandura's research on self-efficacy [40]. In Davis' study, the perceived usefulness scale attained a Cronbach's alpha reliability of 0.97 
for both the electronic mail and XEDIT systems, while the perceived ease of use achieved a reliability of 0.86 [37]. This scale has been adopted in many studies to examine the applicability of information technology (IT) in relation to ease of use and usefulness [41,42] However, few studies have been conducted on the adoption of this model to test L2 learners' acceptance of implementing IT in the classroom. More specifically, the use of breakout groups to help teach translation has been under researched.

\section{Data Analysis}

In this chapter, statistical data analysis is conducted, as follows: the main characteristics of the sample are presented in Section 4.1 to describe the participants' personal information (i.e., gender, age, and university level). Reliability and validity analysis is then conducted in Section 4.2 to evaluate the reliability and validity of the study dimensions: usefulness and ease of use. Meanwhile, Section 4.3 is devoted to confirmatory factor analysis, with the aim of testing how well the measured variables represent their dimensions. Finally, the results obtained to answer the research questions are presented.

\subsection{Sample Characteristics}

This section presents the main sample characteristics. The following tables offer a picture of the participants' personal information (i.e., gender, age, university level).

The following, Table 1, illustrates that the whole sample is female.

Table 1. Frequency table for gender.

\begin{tabular}{ccc}
\hline & Frequency & Percentage \\
\hline Female & 54 & 100.0 \\
\hline Male & 0 & 0.0 \\
\hline Total & 54 & 100.0 \\
\hline
\end{tabular}

The following, Table 2, illustrates that the percentage of sampled participants aged between 18 and 20 years was $1.9 \% ; 79.6 \%$ of the sampled participants were aged between 20 and 22 years; $16.7 \%$ were aged between 22 and 24 years; $1.9 \%$ were aged over 24 years. Figure 3 below illustrates percentages for age for the participants.

Table 2. Frequency table for age.

\begin{tabular}{ccc}
\hline & Frequency & Percentage \\
\hline $18-20$ years & 1 & 1.9 \\
\hline $20-22$ years & 43 & 79.6 \\
\hline 22-24 years & 9 & 16.7 \\
\hline Over 24 years & 1 & 1.9 \\
\hline Total & 54 & 100.0 \\
\hline
\end{tabular}

The following, Table 3, illustrates that the percentage of participants in the sample at university level 6 was $98.1 \%$, and the percentage of sampled participants at university level 7 was $1.9 \%$. This level is the final level before graduation. Figure 4 below illustrates Percentages for university level.

Table 3. Percentages for university level.

\begin{tabular}{ccc}
\hline & Frequency & Percentage \\
\hline Level 6 & 53 & 98.1 \\
\hline Level 7 & 1 & 1.9 \\
\hline Total & 54 & 100.0 \\
\hline
\end{tabular}




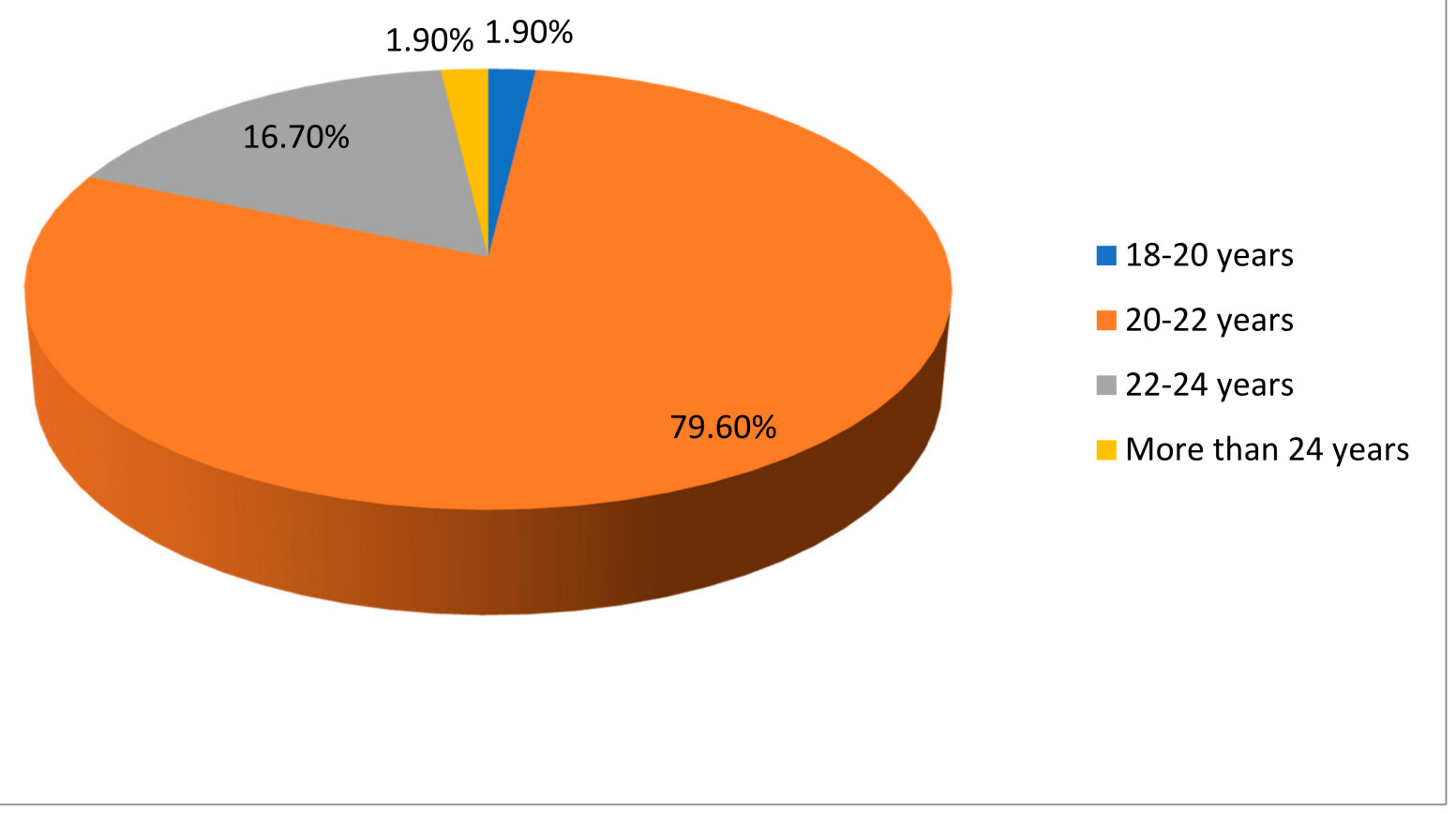

Figure 3. Percentages for age.

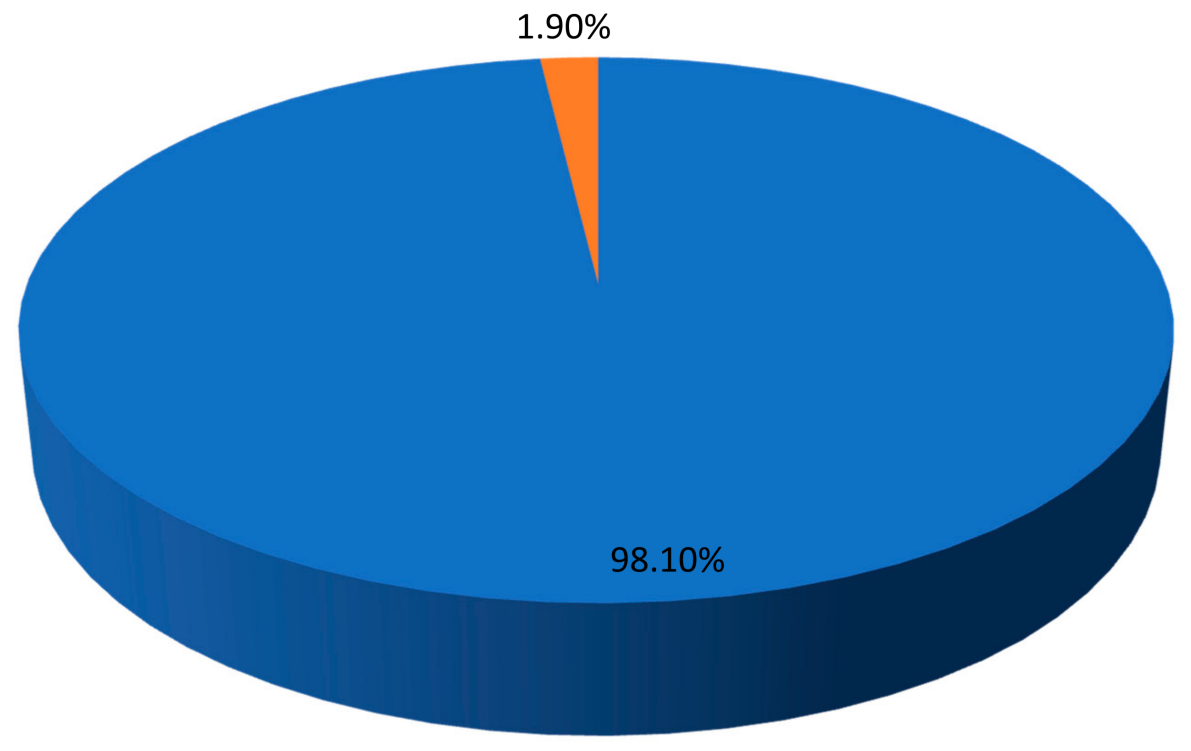

- Level 6

Level 7

Figure 4. Percentages for university level.

The following, Table 4, illustrates that all the participants in the sample were studying translation, more specifically, at the College of Language and Translation at Al-Imam University. 
Table 4. Frequency table for courses.

\begin{tabular}{ccc}
\hline & Frequency & Percentage \\
\hline Translation & 54 & 100.0 \\
\hline Other courses & 0 & 0.0 \\
\hline Total & 54 & 100.0 \\
\hline
\end{tabular}

\subsection{Reliability and Validity}

In the original study conducted by Davis [37], Cronbach's alpha was calculated to measure reliability, the results indicated 0.98 for the perceived usefulness scale and 0.94 for the perceived ease of use scale. A pilot study was also conducted in the current study, and only 9 out of the 20 participants involved in the pilot study responded. These participants shared the same characteristics as those sampled for the main study, in terms of gender, age, and year of university study, but they did not participate in the main study. As they had not previously participated in the breakout groups, a video was sent to them to explain how breakout groups operate, and the researcher also demonstrated how breakout groups would be used in the translation class. Cronbach's alpha $(\alpha)$ was calculated for each dimension, with results determined in values ranging between 0 and 1 , and range of between 0.7 and 1 was determined to be acceptable. Thus, the original reliability measure from Davis was used in the current study [37].

The following, Table 5, illustrates that the data were evaluated as reliable, having satisfied the reliability test, as all Cronbach's alpha values exceeded the acceptable value. The Cronbach's alpha value for perceived usefulness was 0.783 (more than 0.7) and the Cronbach's alpha value for perceived ease of use was 0.875 (greater than 0.7 ).

Table 5. Reliability analysis.

\begin{tabular}{ccc}
\hline & No. of Items & Cronbach's Alpha \\
\hline Usefulness & 5 & 0.783 \\
\hline Ease of use & 6 & 0.875 \\
\hline
\end{tabular}

Conversely, in order to evaluate validity, Pearson's correlation coefficients were calculated for each item with its dimension (see Table 6, below).

The above, Table 6, illustrates that the validity of the study was supported. The correlation coefficients of the following items, within the dimension of 'perceived usefulness', were greater than 0.5: work more quickly, increases productivity, effectiveness, makes job easier, and useful. The correlation coefficients of the following items, within the dimension, 'perceived ease of use', were greater than 0.5: easy to learn, controllable, clear and easy to understand, flexible, easy to become skillful, and easy to use.

Table 6. Validity analysis.

\begin{tabular}{cll}
\hline & Correlation & Significance \\
\hline Usefulness & & \\
\hline Work more quickly & $0.806^{* *}$ & 0.000 \\
\hline Increases productivity & $0.680^{* *}$ & 0.000 \\
\hline Effectiveness & $0.593^{* *}$ & 0.000 \\
\hline Makes job easier & $0.765^{* *}$ & 0.000 \\
\hline Useful & $0.803^{* *}$ & 0.000 \\
\hline
\end{tabular}


Table 6. Cont.

\begin{tabular}{cll}
\hline & Correlation & Significance \\
\hline Ease of use & & \\
\hline Easy to learn & $0.816^{* *}$ & 0.000 \\
\hline Controllable & $0.768^{* *}$ & 0.000 \\
\hline Clear and easy to understand & $0.682^{* *}$ & 0.000 \\
\hline Flexible & $0.788^{* *}$ & 0.000 \\
\hline Easy to become skillful & $0.873^{* *}$ & 0.000 \\
\hline Easy to use & $0.817^{* *}$ & 0.000 \\
\hline Correlation is significant at the 0.01 level (two-tailed). &
\end{tabular}

\subsection{Answering the Research Questions}

The following, Table 7, presents the participants' opinions in relation to perceived usefulness and ease of use.

Table 7. Descriptive statistics for perceived usefulness.

\begin{tabular}{|c|c|c|c|c|c|c|c|c|}
\hline Items & Mean & Median & Min & Max & SD & $\%$ & Response & Rank \\
\hline $\begin{array}{l}\text { 1. Using breakout groups on Blackboard in } \\
\text { my translation class would enable me to } \\
\text { accomplish tasks more quickly. }\end{array}$ & 6.13 & 6 & 3 & 7 & 0.97 & $87.6 \%$ & Quite likely & 2 \\
\hline $\begin{array}{l}\text { 2. Using breakout groups on Blackboard in } \\
\text { my translation class would increase } \\
\text { my productivity. }\end{array}$ & 6.11 & 6 & 3 & 7 & 0.95 & $87.3 \%$ & Quite likely & 3 \\
\hline $\begin{array}{l}\text { 3. Using breakout groups on Blackboard } \\
\text { would enhance my effectiveness in } \\
\text { performing tasks. }\end{array}$ & 6.11 & 6 & 4 & 7 & 0.90 & $87.3 \%$ & Quite likely & 4 \\
\hline $\begin{array}{l}\text { 4. Using breakout groups on Blackboard } \\
\text { would make it easier to perform my tasks. }\end{array}$ & 6.11 & 6 & 3 & 7 & 1.02 & $87.3 \%$ & Quite likely & 5 \\
\hline $\begin{array}{l}\text { 5. I would find breakout groups useful in } \\
\text { my translation class. }\end{array}$ & 6.30 & 7 & 3 & 7 & 0.98 & $89.9 \%$ & Extremely likely & 1 \\
\hline Usefulness & 6.15 & 6 & 3 & 7 & 0.71 & $87.9 \%$ & Quite likely & \\
\hline
\end{tabular}

\subsubsection{Research Question One}

To what extent do learners in a translation class find breakout groups on Blackboard useful for working collaboratively?

The above, Table 7 , illustrates that the fifth item in usefulness had the highest mean value (6.3 out of 7$)$.

The following, Table 8, presents the participants' opinions with regard to the items relating to perceived usefulness-work more quickly, increases productivity, effectiveness, makes job easier, and useful.

The following table presents the main descriptive statistics (means, standard deviations) for the following items, relating to perceived usefulness: work more quickly, increases productivity, effectiveness, makes job easier, and useful. In order to answer the first research question, a one-sample $t$-test or a Wilcoxon signed rank test were used. The one-sample $t$-test contained four main assumptions, as follows: the dependent variable must be normally distributed, the dependent variable must be continuous, the observations must be independent, and the dependent variable must not contain outliers. If any of these assumptions were violated, the Wilcoxon signed rank test was used as an alternative to the one-sample $t$-test. 
Table 8. Frequency table for perceived usefulness.

\begin{tabular}{|c|c|c|c|c|c|c|c|c|}
\hline & & $\begin{array}{l}\text { Extremely } \\
\text { Unlikely }\end{array}$ & $\begin{array}{l}\text { Quite } \\
\text { Unlikely }\end{array}$ & $\begin{array}{l}\text { Slightly } \\
\text { Unlikely }\end{array}$ & $\begin{array}{l}\text { Neither } \\
\text { Likely nor } \\
\text { Unlikely }\end{array}$ & $\begin{array}{l}\text { Slightly } \\
\text { Likely }\end{array}$ & $\begin{array}{l}\text { Quite } \\
\text { Likely }\end{array}$ & $\begin{array}{l}\text { Extremely } \\
\text { Likely }\end{array}$ \\
\hline \multicolumn{9}{|l|}{ Usefulness } \\
\hline \multirow{2}{*}{$\begin{array}{l}\text { 1. Using breakout groups on Blackboard in my translation } \\
\text { class would enable me to accomplish tasks more quickly. }\end{array}$} & $\mathrm{F}$ & 0 & 0 & 2 & 1 & 7 & 22 & 22 \\
\hline & $\mathrm{P}$ & 0.0 & 0.0 & 3.7 & 1.9 & 13.0 & 40.7 & 40.7 \\
\hline \multirow{2}{*}{$\begin{array}{l}\text { 2. Using breakout groups on Blackboard in my translation } \\
\text { class would increase my productivity. }\end{array}$} & $\mathrm{F}$ & 0 & 0 & 1 & 3 & 6 & 23 & 21 \\
\hline & $\mathrm{P}$ & 0.0 & 0.0 & 1.9 & 5.6 & 11.1 & 42.6 & 38.9 \\
\hline \multirow{2}{*}{$\begin{array}{l}\text { 3. Using breakout groups on Blackboard would enhance my } \\
\text { effectiveness in my tasks. }\end{array}$} & $\mathrm{F}$ & 0 & 0 & 0 & 4 & 7 & 22 & 21 \\
\hline & $\mathrm{P}$ & 0.0 & 0.0 & 0.0 & 7.4 & 13 & 40.7 & 38.9 \\
\hline \multirow{2}{*}{$\begin{array}{l}\text { 4. Using breakout groups on Blackboard would make it easier } \\
\text { to perform my tasks. }\end{array}$} & $\mathrm{F}$ & 0 & 0 & 2 & 2 & 7 & 20 & 23 \\
\hline & $\mathrm{P}$ & 0.0 & 0.0 & 3.7 & 3.7 & 13.0 & 37.0 & 42.6 \\
\hline \multirow{2}{*}{ 5. I would find breakout groups useful in my translation class. } & $\mathrm{F}$ & 0 & 0 & 2 & 1 & 5 & 17 & 29 \\
\hline & $\mathrm{P}$ & 0.0 & 0.0 & 3.7 & 1.9 & 9.3 & 31.5 & 53.7 \\
\hline
\end{tabular}

The following, Table 9, presents the results of the first assumption (the normality assumption). In this table, the normality assumption for perceived usefulness was evaluated using Kolmogorov-Smirnov tests. From these results, it may be noted that the normality assumption for usefulness was violated, as the value of significance was less than 0.05 . Thus, the Wilcoxon signed rank test was used as a non-parametric alternative to the one-sample $t$-test.

Table 9. Normality tests.

\begin{tabular}{ccc}
\hline & Statistic & Significance \\
\hline Usefulness & 0.147 & 0.000 \\
\hline
\end{tabular}

The following Table 10 demonstrates that perceived usefulness was a significant factor, as the value of significance was less than 0.05 . The learners in the translation class found that breakout groups on Blackboard were useful for working collaboratively.

Table 10. Wilcoxon signed rank tests.

\begin{tabular}{ccccc}
\hline & Mean & Std Dev & Statistic & Significance \\
\hline Usefulness & 6.15 & 0.71 & 1483.0 & 0.000 \\
\hline
\end{tabular}

\subsubsection{Research Question Two}

To what extent do learners in a translation class find breakout groups on Blackboard easy to use for working collaboratively?

The following, Tables 11 and 12, presents the main descriptive statistics (means, standard deviations) for the following items relating to perceived ease of use: easy to learn, controllable, clear and easy to understand, flexible, easy to become skillful, and easy to use.

Table 11. Descriptive statistics for perceived ease of use.

\begin{tabular}{ccccccccc}
\hline Items & Mean & Median & Min & Max & SD & $\%$ & Response & Rank \\
\hline $\begin{array}{c}\text { 1. Learning how to perform the task using } \\
\text { breakout groups would be easy for me. }\end{array}$ & 6.02 & 6 & 2 & 7 & 1.17 & $86.0 \%$ & Quite likely & 3 \\
\hline $\begin{array}{c}\text { 2. I would find it easy to achieve what I } \\
\text { want through breakout groups. }\end{array}$ & 5.85 & 6 & 1 & 7 & 1.31 & $83.6 \%$ & Quite likely & 6 \\
\hline $\begin{array}{c}\text { 3. My interaction using breakout groups } \\
\text { would be clear and easy to understand. }\end{array}$ & 5.93 & 6 & 1 & 7 & 1.20 & $84.7 \%$ & Quite likely \\
\hline
\end{tabular}


Table 11. Cont.

\begin{tabular}{|c|c|c|c|c|c|c|c|c|}
\hline Items & Mean & Median & Min & Max & SD & $\%$ & Response & Rank \\
\hline $\begin{array}{l}\text { 4. I would find breakout groups flexible in } \\
\text { the way that they enabled me to interact } \\
\text { with my classmates. }\end{array}$ & 6.26 & 6.30 & 3 & 7 & 0.99 & $89.4 \%$ & Extremely likely & 1 \\
\hline $\begin{array}{l}\text { 5. It would be easy for me to become } \\
\text { skillful at using breakout groups. }\end{array}$ & 6.02 & 6 & 2 & 7 & 1.17 & $86.0 \%$ & Quite likely & 4 \\
\hline $\begin{array}{l}\text { 6. I would find breakout groups easy } \\
\text { to use. }\end{array}$ & 6.20 & 6 & 3 & 7 & 0.96 & $88.6 \%$ & Extremely likely & 2 \\
\hline Ease of use. & 6.05 & 6 & 3 & 7 & 0.90 & $86.4 \%$ & Quite likely & \\
\hline
\end{tabular}

Table 12. Table of frequency for perceived ease of use.

\begin{tabular}{|c|c|c|c|c|c|c|c|c|}
\hline & & $\begin{array}{l}\text { Extremely } \\
\text { Unlikely }\end{array}$ & $\begin{array}{l}\text { Quite } \\
\text { Unlikely }\end{array}$ & $\begin{array}{l}\text { Slightly } \\
\text { Unlikely }\end{array}$ & $\begin{array}{l}\text { Neither } \\
\text { Likely nor } \\
\text { Unlikely }\end{array}$ & $\begin{array}{l}\text { Slightly } \\
\text { Likely }\end{array}$ & $\begin{array}{l}\text { Quite } \\
\text { Likely }\end{array}$ & $\begin{array}{l}\text { Extremely } \\
\text { Likely }\end{array}$ \\
\hline \multirow{2}{*}{$\begin{array}{l}\text { 1. Learning how to perform tasks using breakout groups } \\
\text { would be easy for me. }\end{array}$} & $\mathrm{F}$ & 0 & 1 & 2 & 2 & 8 & 18 & 23 \\
\hline & $\mathrm{P}$ & 0.0 & 1.9 & 3.7 & 3.7 & 14.8 & 33.3 & 42.6 \\
\hline \multirow{2}{*}{$\begin{array}{l}\text { 2. I would find it easy to achieve what I want through } \\
\text { breakout groups. }\end{array}$} & $\mathrm{F}$ & 1 & 0 & 2 & 5 & 8 & 17 & 21 \\
\hline & $\mathrm{P}$ & 1.9 & 0.0 & 3.7 & 9.3 & 14.8 & 31.5 & 38.9 \\
\hline \multirow{2}{*}{$\begin{array}{l}\text { 3. My interaction using breakout groups would be clear and } \\
\text { easy to understand. }\end{array}$} & $\mathrm{F}$ & 1 & 0 & 1 & 4 & 7 & 22 & 19 \\
\hline & $\mathrm{P}$ & 1.9 & 0.0 & 1.9 & 7.4 & 13.0 & 40.7 & 35.2 \\
\hline \multirow{2}{*}{$\begin{array}{l}\text { 4. I would find the breakout groups flexible in the way that } \\
\text { they enabled me to interact with my classmates. }\end{array}$} & $\mathrm{F}$ & 0 & 0 & 2 & 2 & 3 & 20 & 27 \\
\hline & $B$ & 0.0 & 0.0 & 3.7 & 3.7 & 5.6 & 37.0 & 50.0 \\
\hline \multirow{2}{*}{$\begin{array}{l}\text { 5. It would be easy for me to become skillful at using } \\
\text { breakout groups. }\end{array}$} & $\mathrm{F}$ & 0 & 1 & 2 & 2 & 8 & 18 & 23 \\
\hline & B & 0.0 & 1.9 & 3.7 & 3.7 & 14.8 & 33.3 & 42.6 \\
\hline \multirow{2}{*}{ 6. I would find breakout groups easy to use. } & $\mathrm{F}$ & 0 & 0 & 1 & 2 & 8 & 17 & 26 \\
\hline & $\mathrm{P}$ & 0.0 & 0.0 & 1.9 & 3.7 & 14.8 & 31.5 & 48.1 \\
\hline
\end{tabular}

The above table illustrates that the fourth item (flexible) had the highest mean value (6.26 out of 7$)$.

The following table presents the participants' opinions with regard to the following items, relating to perceived ease of use: easy to learn, controllable, clear and easy to understand, flexible, easy to become skillful, and easy to use.

In order to answer the second research question, one-sample $t$-test or Wilcoxon signed rank test was used. The one-sample $t$-test contains four main assumptions, as follows: the dependent variable must be normally distributed, the dependent variable must be continuous, the observations must be independent, and the dependent variable should not contain outliers. If these assumptions were violated, a Wilcoxon signed rank test would be used as an alternative to the one-sample $t$-test.

The following Table 13 presents the results for the first assumption (the normality assumption). In this table, the normality assumption for the 'ease of use' dimension was evaluated using Kolmogorov-Smirnov tests. From these results, it may be noted that the normality assumption was violated for ease of use, as the value of significance was less than 0.05. Thus, the Wilcoxon signed rank test was used as a non-parametric alternative to the one-sample $t$-test.

Table 13. Normality tests.

\begin{tabular}{ccc}
\hline & Statistic & Significance \\
\hline Ease of use & 0.220 & 0.000 \\
\hline
\end{tabular}

The following Table 14 illustrates that perceived ease of use was a significant factor since the value of significance was less than 0.05 . The learners in the translation class found that breakout groups on Blackboard were useful and easy to use for working collaboratively. 
Table 14. Wilcoxon signed rank tests.

\begin{tabular}{ccccc}
\hline & Mean & Std Dev & Statistic & Significance \\
\hline Ease of use & 6.05 & 0.90 & 1475.0 & 0.000 \\
\hline
\end{tabular}

\section{Discussion}

The results revealed the learners' opinions of using breakout groups on Blackboard. Two factors in the survey were considered: usefulness and ease of use. The learners subsequently expressed positive views of breakout groups.

Regarding the first factor, concerning usefulness, several items received positive responses, such as 'Using breakout groups on Blackboard in my translation class would enable me to accomplish tasks more quickly'. This advantage could be very helpful, specifically because the learners would be able to enjoy privacy in their groups without feeling embarrassed about making mistakes. They would also negotiate solutions to any problems that they faced in translation. This aspect of active learning has been covered by [25].

Based on that was agreed on by the participants, for example, 'I would find breakout groups useful in my translation class', it was gathered that they could finish their work more quickly, as they would be assisting and making suggestions to each other. Moreover, the participants 'Strongly agreed' on the following item: 'Using breakout groups on Blackboard in my translation class would increase my productivity'. In particular, the learners could share their audio content and written text on the screen, whereupon they would all comment on each other's work, thereby leading to better learning and better work being produced within the limited time spent in class. In some ways, this is similar to the study conducted by [33], where it was found that text and audio messaging helped the learners in their learning.

In relation to the second factor mentioned above, namely ease of use, the participants were also positive in their responses, agreeing on most of the items. The most highly ranked item, with which most of the participants agreed, was 'I would find breakout groups flexible in the way that they enabled me to interact with my classmates'. This indicated that interaction was the most important outcome of using breakout groups. This is because it highlights scaffolding and collaborative learning as being important for active learning [25].

Another important factor of using breakout groups in teaching is their simplicity in implementation. The participants 'Strongly agreed' on this survey item, stating, 'I would find breakout groups easy to use'. For example, all the learners had to do was interact with each other and save their interactions to send to their teacher later, as described by the course instructor. The item ranked third in the survey, which also received highly positive responses, was the following: 'Learning how to perform the task using breakout groups would be easy for me'. If the technology itself is easy to use, then it will promote concentration on the task and the ability to perform it properly within the required time.

All other items were positively agreed with by the participants and the highestranking items have been discussed here. It was found that maximizing the potential of any technology that is used will lead to a better teaching and learning experience, as it will add variety to the process, more specifically in an EFL environment.

\section{Conclusions}

Based on the data presented and the ensuing discussion in this study, it may be concluded that educators need to invest more thought and self-development to advance their teaching, which would also mean that some expectations might need to be readjusted. Despite the many obstacles identified in e-learning, however, the educators sampled for this study highlighted its opportunities as well as its challenges. One especially pragmatic solution proposed was increased flexibility, which would enable students to learn independently. Additionally, e-learning has triggered reflection among educators with regard to their teaching, which could lead to improved practice [43,44]. 


\section{Limitations and Implications for Practice}

In the current study, the following limitations were noted:

1. The participants were exclusively female, due to the context of the study and social restrictions of the country.

2. The data were collected over a period of two weeks only, as the teacher used the breakout groups.

3. The data were only collected from translation classes.

4. Furthermore, according to the results, the following implications may be drawn for actual practice.

5. Breakout groups could be included in online translation classes to help learners to collaborate in groups.

6. Attempts could be made to use this feature on other online courses that might require collaboration, like L2 writing classes, where the learners need each other's help under the teacher's guidance.

7. Breakout groups should be included in a male section to examine their suitability, using the same scale.

Author Contributions: Conceptualization, I.O. and T.E.; methodology I.O. and T.E.; software, I.O. and T.E.; validation, I.O. and T.E.; formal analysis, I.O. and T.E.; investigation, I.O. and T.E.; resources, I.O. and T.E.; data curation, I.O. and T.E.; writing-original draft preparation, I.O. and T.E.; writingreview and editing, I.O. and T.E.; visualization, I.O. and T.E.; supervision, I.O. and T.E.; project administration, I.O. and T.E.; funding acquisition, I.O. and T.E. All authors have read and agreed to the published version of the manuscript.

Funding: This research was supported by the Deanship of Scientific Research, Imam Mohammad Ibn Saud Islamic University (IMSIU), Saudi Arabia, Grant No. 21-13-18-019.

Informed Consent Statement: Informed consent was obtained from all subjects involved in the study.

Conflicts of Interest: The authors declare no conflict of interest.

\section{References}

1. Laal, M.; Ghodsi, S.M. Benefits of collaborative learning. Procedia-Soc. Behav. Sci. 2012, 31, 486-490. [CrossRef]

2. Nicola, M.; Alsafi, Z.; Sohrabi, C.; Kerwan, A.; Al-Jabir, A.; Iosifidis, C.; Agha, M.; Agha, R. The socio-economic implications of the coronavirus pandemic (COVID-19): A review. Int. J. Surgery. 2020, 78, 185-193. [CrossRef]

3. World Health Organization. COVID-19 Weekly Epidemiological Update, 3 November 2020. Available online: https://www.who. int/emergencies/diseases/novel-coronavirus-2019?adgroupsurvey (accessed on 3 October 2021).

4. Oraif, I.; Elyas, T. The impact of COVID-19 on learning: Investigating EFL learners' engagement in online courses in Saudi Arabia. Educ. Sci. 2021, 11, 99. [CrossRef]

5. Basalamah, O.; Elyas, T. The Emergent Effects of a Wired World to an Educational Paradigm Shift in Saudi Arabia: A Case Study. Procedia-Soc. Behav. Sci. 2012, 47, 1534-1538. [CrossRef]

6. Basalamah, O.; Elyas, T. Conceptualizing the virtual learning space(s) in Saudi Arabia: A Foucauldian panoptic approach. Int. J. Engl. Lang. Teach. 2014, 2, 1-15.

7. Aldwaihi, A. Available online: https://www.okaz.com.sa/articles/authors/2034871 (accessed on 26 July 2020).

8. Al-Bogami, B.; Elyas, T. Promoting Middle School Students' Engagement through Incorporating iPad Apps in EFL/ESL Classes. SAGE Open 2020, 10, 2158244020926570. [CrossRef]

9. Saati, A. Distance Learning and Coronavirus Crisis. Aleqt. Available online: https://www.aleqt.com/2020/04/05/article_179757 6.html (accessed on 5 April 2020).

10. MOE. Ministry of Education-My School Virtual Classrooms. Available online: https://www.moe.gov.sa/ar/news/pages/mn-20 20-876.aspx (accessed on 26 July 2020).

11. Alamer, O. The Culture of Distance Learning. Al-Jazirah Newspaper, 24 March 2020. Available online: https:/ /www.al-jazirah. com/2020/20200324/ar3.htm (accessed on 20 August 2020).

12. Khalid, T. Distance Learning Amid Coronavirus to Help School Dropouts in Saudi Arabia: Minister. Al Arabiya (English). Available online: https:/ / english.alarabiya.net/en/coronavirus/2020/05/15/Distance-learning-amid-coronavirus-to-helpschool-dropouts-in-Saudi-Arabia-Minister (accessed on 14 May 2020).

13. Alfifi, A. After Coronavirus: Our Education towards the Best. Alriyadh Newspaper. Available online: http://www.alriyadh.com/ 1816856 (accessed on 20 April 2020). 
14. Al-Mayman, H. Saudi E-Learning Portal Ushers in New Normal with Virtual Classrooms. 512 Arab News. Available online: https://www.arabnews.com/node/1730541/saudi-arabia (accessed on 6 September 2020).

15. AlSalih, K. Saudi Study for Assessment of Remote Learning Process. Alwatan Newspaper. Available online: https://www.alwatan. com.sa/article/1048932 (accessed on 20 June 2020).

16. Barakat, R. Extension of Distance Learning in Saudi Arabia. Mhtwyat. Available online: https://bit.ly/35gxtPG (accessed on 11 August 2020).

17. Alshehri, Y.A.; Mordhah, N.; Alsibiani, S.; Alsobhi, S.; Alnazzawi, N. How the Regular Teaching Converted to Fully Online Teaching in Saudi Arabia during the Coronavirus COVID-19. Creat. Educ. 2020, 11, 985-996. [CrossRef]

18. Almaghaslah, D.; Alsayari, A. The Effects of the 2019 Novel Coronavirus Disease (COVID-19) Outbreak on Academic Staff Members: A Case Study of a Pharmacy School in Saudi Arabia. Risk Manag. Healthc. Policy 2020, 13, 795-802. [CrossRef] [PubMed]

19. Alqraini, F.M.; Alasim, K.N. Distance Education for d/Deaf and Hard of Hearing Students during the COVID-19 Pandemic in Saudi Arabia: Challenges and Support. Res. Dev. Disabil. 2021, 117, 104059. [CrossRef] [PubMed]

20. Al-Samiri, R.A. English language teaching in Saudi Arabia in response to the COVID-19 pandemic: Challenges and positive outcomes. Arab. World Engl. J. Spec. Issue Covid 2021, 19, 147-159. [CrossRef]

21. Vollbrecht, P.J.; Porter-Stransky, K.A.; Lackey-Cornelison, W.L. Lessons learned while creating an effective emergency remote learning environment for students during the COVID-19 pandemic. Adv. Physiol. Educ. 2020, 44, 722-725. [CrossRef]

22. Gruber, A.; Bauer, E. Fostering interaction in synchronous online class sessions with foreign language learners. Teach. Technol. Teach. Educ. Dur. COVID-19 Pandemic Stories Field 2020, 175-178.

23. Marshall, H.W.; Kostka, I. Fostering teaching presence through the synchronous online flipped learning approach. Tesl-Ej 2020, 24, n2.

24. De Pryck, D.; De Pryck, K. Building a community and facilitating social presence in an online learning environment: Why? and how? In Society for Information Technology \& Teacher Education International Conference; Association for the Advancement of Computing in Education (AACE): Waynesville, NC, USA, 2021; pp. 1188-1190.

25. Prince, M. Does active learning work? A review of the research. J. Eng. Educ. 2004, 93, 223-231. [CrossRef]

26. Lougheed, J.; Kirkland, J.; Newton, G. Using Breakout Groups as an Active Learning Technique in a Large Undergraduate Nutrition Classroom at the University of Guelph. Can. J. Sch. Teach. Learn 2012, 3, 6. [CrossRef]

27. Daniel, E.A. Exploring the process of assessment: Report on the ATS workshop on assessing theological learning. Theol. Educ. 2003, 3, 3-100.

28. Pritchard, G.E. Improving Learning with Information Technology: Report of a Workshop (Washington, DC, January 24-25, 2001); National Academy Press: Washington, DC, USA, 2002.

29. Chandler, K. Using Breakout Rooms in Synchronous Online Tutorials. J. Perspect. Appl. Acad. Pr. 2016, 4, 16-23. [CrossRef]

30. Martin, F.; Parker, M.A. Use of synchronous virtual classrooms: Why, who, and how? J. Online Learn. Teach. 2014, 10, 192-210.

31. Saltz, J.; Heckman, R. Using Structured Pair Activities in a Distributed Online Breakout Room. Online Learn. 2020, 24, 227-244. [CrossRef]

32. Rahayu, D. Students' E-Learning Experience through a Synchronous Zoom Web Conference System. J. ELT Res. Acad. J. Stud. Engl. Lang. Teach. Learning. 2020, 9, 68-79.

33. Murphy, E.; Ciszewska-Carr, J. Instructors' experiences of web based synchronous communication using two-way audio and direct messaging. Australas. J. Educ. Technol. 2007, 23. [CrossRef]

34. Kohnke, L.; Moorhouse, B.L. Facilitating Synchronous Online Language Learning through Zoom. RELC J. 2020, 0033688220937235. [CrossRef]

35. Angelone, L.; Warner, Z.; Zydney, J.M. Optimizing the Technological Design of a Blended Synchronous Learning Environment. Online Learn. 2020, 24, 222-240. [CrossRef]

36. Cadieux, M.; Campos-Zamora, M.; Zagury-Orly, I.; Dzara, K. Journal Club Using Virtual Breakout Rooms: Interactive Continuing Education with No Learner Preparation during COVID-19. J. Contin. Educ. Health Prof. 2020, 40, 217-219. [CrossRef] [PubMed]

37. Davis, F.D. Perceived usefulness, perceived ease of use, and user acceptance of information technology. MIS Q. 1989, 13, 319-340. [CrossRef]

38. Robey, D. User attitudes and management information system use. Acad. Manag. J. 1979, 22, 527-538.

39. Bandura, A. Self-efficacy mechanism in human agency. Am. Psychol. 1982, 37, 122. [CrossRef]

40. Davis, F.D.; Bagozzi, R.P.; Warshaw, P.R. Extrinsic and intrinsic motivation to use computers in the workplace 1. J. Appl. Soc. Psychol. 1992, 22, 1111-1132. [CrossRef]

41. Venkatesh, V. Determinants of Perceived Ease of Use: Integrating Control, Intrinsic Motivation, and Emotion into the Technology Acceptance Model. Inf. Syst. Res. 2000, 11, 342-365. [CrossRef]

42. Venkatesh, V.; Morris, M.G.; Davis, G.B.; Davis, F.D. User acceptance of information technology: Toward a unified view. MIS Q. 2003, 27, 425-478. [CrossRef]

43. Müller, A.M.; Goh, C.; Lim, L.Z.; Gao, X. COVID-19 Emergency eLearning and Beyond: Experiences and Perspectives of University Educators. Educ. Sci. 2021, 11, 19. [CrossRef]

44. Khalifé, K. Pragmatic Tips for Optimizing Remote Classroom Instruction in High School and College. Fr. Rev. 2020, 94, 17-21. [CrossRef] 